\title{
PLAUČIŲ IMUNOHISTOCHEMINIAI POKYČIAI SERGANT LĖTINE OBSTRUKCINE PLAUČIŲ LIGA IR ASTMA
}

\author{
ASTA JANUŠKEVIČIŪTÉ
}

KMU PULMONOLOGIJOS IR IMUNOLOGIJOS KLINIKA

Reikšminiai žodžiai: lètinė obstrukcinė plaučių liga (LOPL), astma, imunohistochemija, patogenezė.

Santrauka. Astma ir lètinė obstrukcinė plaučių liga (LOPL) - lètinės, obstrukcinės kvejpavimo takų uždegimo ligos, kurios skiriasi savo klinika bei patogeneze. Astmos bei LOPL patogenezèje dalyvauja daug ląstelių. Imunohistocheminiais metodais nustatomas padidèjęs neutrofilų, makrofagų bei CD8+ T limfocitų kiekis LOPL atvejais ir padidejęs eozinofilų, putliųų ląstelių, CD4+ T limfocitų kiekis bronchų astmos atvejais.

Astma ir lètinè obstrukcinè plaučių liga (LOPL) - lètinès, obstrukcinès kvėpavimo takų uždegimo ligos, kurios skiriasi savo klinika bei patogeneze (1 pav). Šių liguc patogenezèje dalyvauja ịvairios imuninès ląstelès, ju išskiriami mediatoriai ir adhezijos molekulès, kurias nustatyti padeda imuniniai tyrimai, vienas iš ju - imunohistocheminis.

Imunohistocheminis tyrimas - tai antigenų nustatymas ligonio audiniuose ar skysčiuose, kai naudojant fermentus ir fermentuc kompleksus bespalviai chromogenai paverčiami spalvotais junginiais. Tyrimo pavadinimas sudarytas iš dviejų dalių: imuno - rodo, kad tiriant naudojami antikūnai, histo - reiškia audini (skirtingai nuo imunocitocheminiu tyrimų, kuriais tiriamos tik ląstelès, o ne audinys), kuriame ieškoma įvairių antigenų. Klinikinejje praktikoje imunohistocheminiai tyrimai dažniausiai taikomi diagnozuojant navikus. LOPL ir astmos atvejais imunohistocheminiai tyrimai atliekami siekiant suvokti

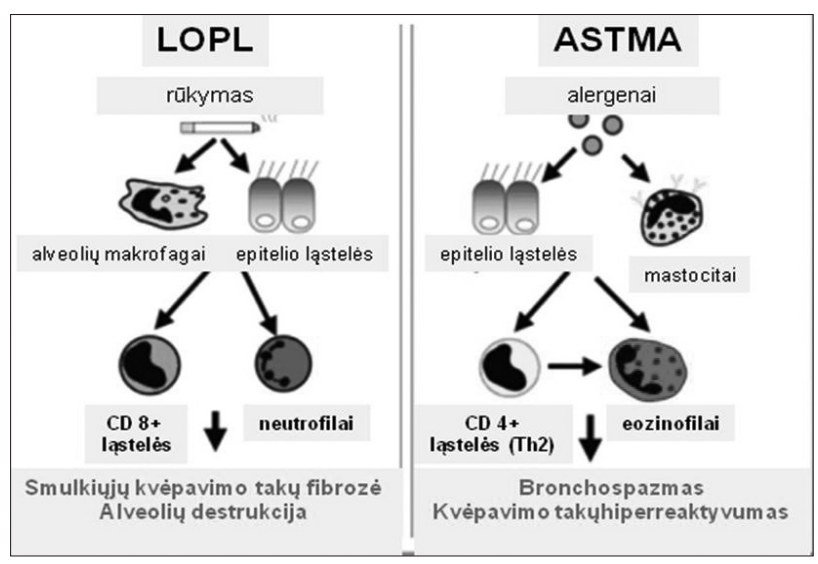

1 pav. LOPL IR ASTMOS PATOGENEZĖS SKIRTUMAI patogenezę, ieškant ligos sunkumo kriterijų, vertinant gydymo veiksmingumą.

\section{LOPL PATOGENEZE்}

Sergant LOPL, kvépavimo takų uždegimą dažniausiai sąlygoja rūkymas, kvėpavimo takų nepraeinamumas yra lètinis, progresuojantis, silpniau reaguojama i inhaliuojamuosius vaistus. Dél lètinio kvépavimo takų uždegimo ar provokuojančiu veiksnių bronchų gleivinę ir pogleivị infiltruoja uždegimo ląstelès (makrofagai, CD8 T limfocitai, neutrofilai, eozinofilai). Pažeidžiamos visos kvẻpavimo taku epitelio ląstelès: virpamosios - sutrinka mukociliarinis klirensas; taurinès - sutrinka sekrecinè epitelio funkcija, sustiprèja sekrecija, atsiranda bronchų sekreto sąstovis, reologinių sekreto pokyčių; pamatinès - sutrinka regeneracija. Uždegimo ląstelių išskiriami mediatoriai skatina virpamojo epitelio metaplaziją ì daugiasluoksnị plokščią̧j epiteli, esant ląstelių pažeidimui bei sekreto reologinių

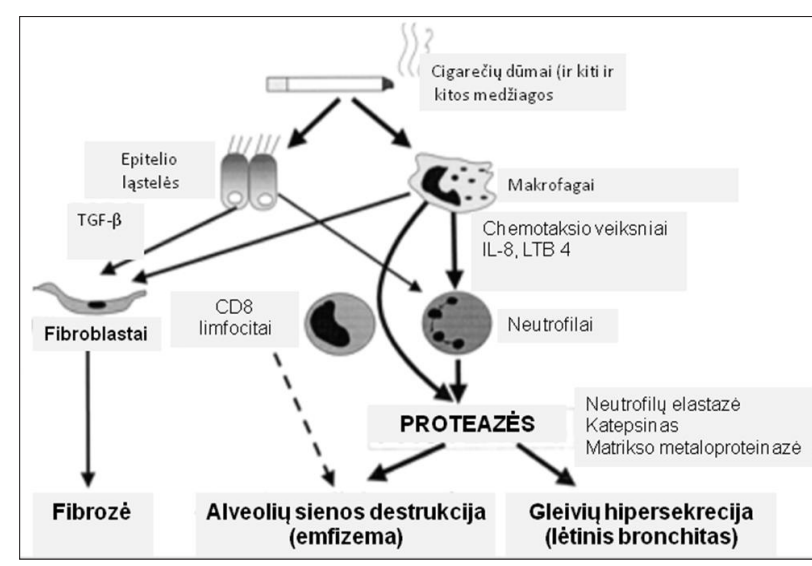

2 pav. LOPL PATOGENEZĖ 

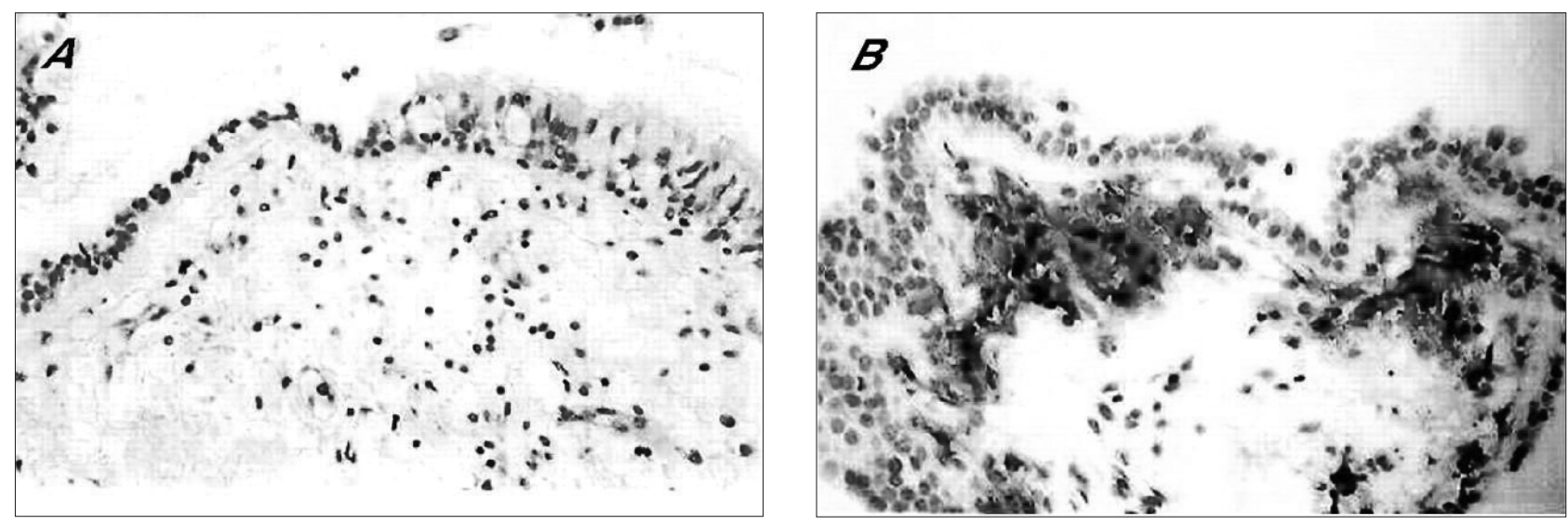

4 pav. NEUTROFILY ELASTAZĖ, NUSTATYTA IMUNOHISTOCHEMINIU METODU, STABILIA ASTMA SERGANČIO LIGONIO PLAUČIY AUDINYJE (A) BEI ASTMAI PAŪMĖJUS (B)

savybių pokyčiams kvejpavimo takuose telkiasi bakterijos. Dèl uždegimo ląstelių ir mikroorganizmų išskiriamų proteazių bei aktyviųjų deguonies junginių sutrinka proteaziu ir antiproteazių bei oksidantu ir antioksidantu pusiausvyra, irsta jungiamasis kvejpavimo takų ir plaučių parenchimos audinys. Uždegimo ląstelių išskiriamos biologiškai aktyvios medžiagos (histaminas, leukotrienai ir kitos) bei dengiamojo epitelio pažeidimas lemia bronchų hiperreaktyvumą ir spazmą. Ligai užsitęsus, išryškèja gleivinès hiperplazija, bronchų lygiưjų raumenų hipertrofija, struktūrinių ir funkcinių smulkiųjų bronchų pokyčių (deformacija, sklerozè, obturacija, ekspiracinis bronchų kolapsas bei kt.) ir plaučių parenchimos pokyčių (emfizema, fibrozė, surfaktanto sintezès sutrikimas) (2 pav).

\section{Uždegimo ląstelès ir ju išskiriamos medžiagos}

- Neutrofilai. Skrepliuose, alveolių ir bronchų išplovose (BAL skystyje) bei LOPL sergančio žmogaus plaučių audinio parenchimoje nustatomas padidèjęs aktyvių neutrofilų kiekis. Jie išskiria serino proteazes: neutrofilu elastazę, katepsiną G, proteinazę 3 bei matrikso metaloproteinazes (MMP)-8 ir -9, kurios skatina alveolių destrukciją. Nustatyta, kad yra tiesioginè sąsaja tarp neutrofilų kiekio biopsinèje medžiagoje bei indukuotuose skrepliuose ir LOPL sunkumo (Di Stefano ir kt., 1998) bei plaučių funkcijos prastèjimo (Stanescu ir kt., 1996). Neutrofilu išskiriamos serino proteazès bei oksidantai žaloja plaučių audinị, nors tiesioginio ryšio tarp neutrofilų kiekio ir alveolių destrukcijos nèra nustatyta (Fin-

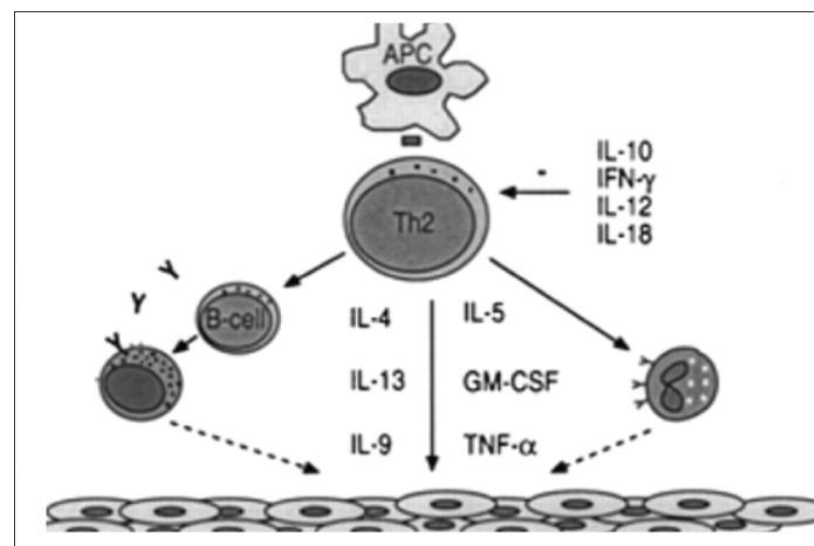

3 pav. CITOKINAI ASTMOS PATOGENEZĖJE

2007 / Nr. 2 (2) kelstein ir kt., 1995). Kvėpavimo takų neutrofilija susijusi su gleiviu hipersekrecija sergant lètiniu bronchitu. Serino proteazès (neutrofilu elastazé, katepsinas G bei MMP-3) stimuliuoja gleives išskiriančias liaukas (Witko-Sarsat ir kt., 1999).

- Makrofagai. Makrofagai - svarbiausios ląstelès LOPL patofiziologijoje (Barnes, 2004). LOPL ligonių kvejpavimo takuose, plaučių parenchimoje, alveolių ir bronchų išplovose bei skrepliuose makrofagu kiekis padidejja nuo penkių iki dešimties kartu, palyginti su sveikais asmenimis. Morfometrinès makrofagų kiekio plaučių audinyje analizès duomenimis esant plaučiuc emfizemai, palyginti su rūkančiais asmenimis, makrofagu parenchimoje padaugeja dvidešimt penkis kartus (Retamales ir kt., 2001) ir jie telkiasi alveolių sienos destrukcijos vietose (Finkelstein ir kt., 1995; Meshi ir kt., 2002). Nustatyta, jog yra tiesioginis ryšys tarp makrofagu kiekio ir LOPL sunkumo (Di Stefano ir kt., 1998). Cigarečiu dūmuose esančios medžiagos suaktyvina makrofagus, kurie išskiria uždegimo mediatorius: MMP-2, MMP-9, MMP-12, katepsiną K, L ir S (Punturieri ir kt., 2000; Russell ir kt., 2002). Sergant LOPL, alveoliu makrofagai išskiria daugiau uždegimo mediatorių, palyginti su rūkančiais, bet LOPL nesergančiais asmenimis (Russell ir kt., 2002). LOPL atveju vyraujanti makrofagu išskiriama proteazė yra MMP-9, o daugelio uždegimo mediatorių makrofaguose išsiskyrimą reguliuoja transkripcijos faktorius NF-B (Di Stefano ir kt., 2002; Caramori ir kt., 2003).

- T limfocitai. Sergant LOPL, plaučių parenchimoje ir centriniuose bei periferiniuose kvėpavimo takuose padaugejja $\mathrm{T}$ limfocitu - labiau CD8+ nei CD4+ ląstelių (Finkelstein ir kt., 1995; O’Shaughnessy ir kt., 1997; Saetta ir kt., 1999; Majo ir kt., 2001; Retamales ir kt., 2001). Pastebèta tiesioginè sąsaja tarp $\mathrm{T}$ limfocituc kiekio, alveolių destrukcijos bei kvèpavimo taku obstrukcijos laipsnio. Be to, nustatyta, kad padideja absoliutusis CD4+ T ląstelių skaičius. CD8+ ląstelès geba sukelti citolizę bei alveolių epitelio ląstelių apoptozę, išskirdamos granzimą-B ir tumoro nekrozès veiksni (TNF)- $\alpha$. Yra nustatyta sąsaja tarp CD8+ ląsteliuc kiekio ir alveolių ląstelių apoptozès esant emfizemai (Majo ir kt., 2001). 


\begin{tabular}{|c|c|c|c|c|c|c|c|}
\hline Limfokinai & & \multicolumn{2}{|c|}{ Uždegimo } & \multicolumn{2}{|c|}{ Slopinantieji citokinai } & \multicolumn{2}{|c|}{ Augimo faktoriai } \\
\hline $\begin{array}{l}\text { IL-15 } \\
\text { IL-16 }\end{array}$ & 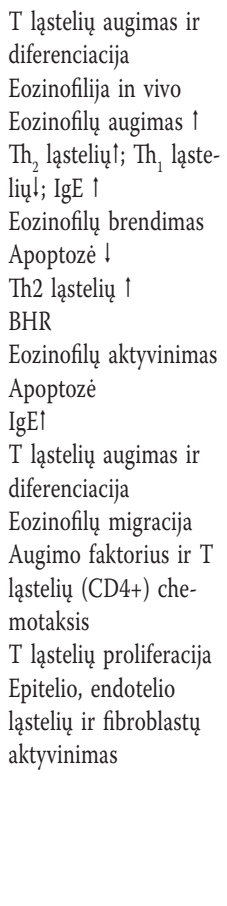 & $\begin{array}{c}\text { IL-6 } \\
\text { IL-11 } \\
\text { GM-CSF }\end{array}$ & 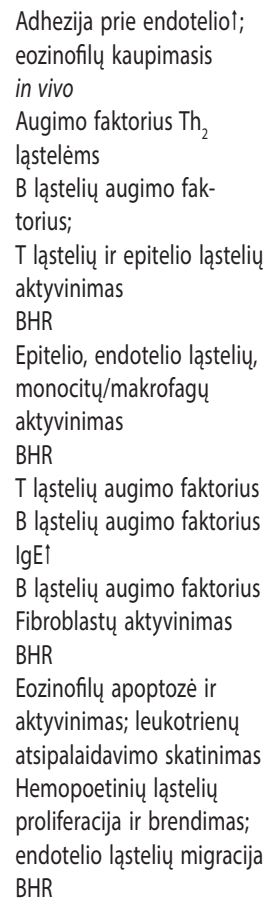 & IL-10 & 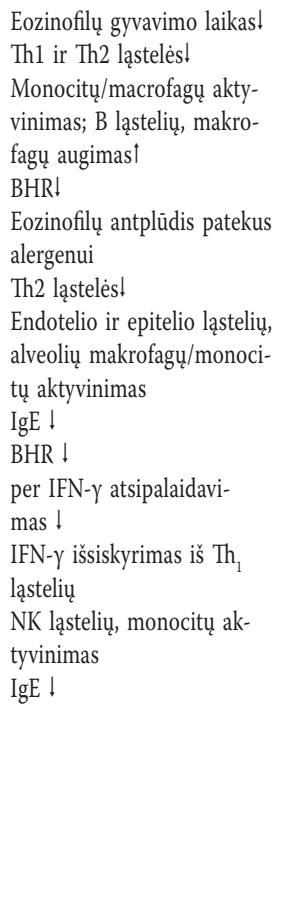 & PDGF & $\begin{array}{l}\text { Fibroblastụ ir kvėpa- } \\
\text { vimo takų raumeninių } \\
\text { ląstelių proliferacija } \\
\text { Kolageno atsipalai- } \\
\text { davimas } \\
\text { T ląstelių prolifera- } \\
\text { cija ! } \\
\text { IL-2 poveikio bloka- } \\
\text { vimas } \\
\text { Fibroblastų prolife- } \\
\text { racija } \\
\text { Chemotaksinis veiks- } \\
\text { nys monocitams, } \\
\text { fibroblastams } \\
\text { Kvėpavimo takų } \\
\text { raumeninių ląstelių } \\
\text { proliferacija ! }\end{array}$ \\
\hline
\end{tabular}

IL - interleukinas; TNF - tumoro nekrozés faktorius; GM-CSF - granuliocitų makrofagų kolonijas stimuliuojantis veiksnys; IFN - interferonas; PDGF - trombocitu augimo faktorius; Th ląstelès - T limfocitai; BHR - bronchu hiperreaktyvumas; ASM - kvèpavimo taku raumeninés ląstelès.

- Eozinofilai. Šių ląstelių radimas biopsinèje medžiagoje LOPL atveju - galimo gero atsako ì gydymą kortikosteroidais prognozès rodiklis, ir verčia susimąstyti, ar kartu nèra kitos ligos - astmos. Eozinofilų kiekio padidejimas pastebimas ir LOPL paūmejjus (Saetta ir kt., 1996).

- Epitelio ląstelès. Epitelio ląstelès, aktyvuotos cigarečių dūmuose esančių medžiagų, gamina uždegimo mediatorius: TNF- $\alpha$, interleukiną (IL)-1 $\beta$, granuliocituc makrofaguc - kolonijas stimuliuojantị veiksnị (GM-CSF) ir IL-8. Smulkiụjų kvėpavimo takų epitelio ląstelès gali būti svarbus transformuojančio augimo veiksnio (TGF)- $\beta$ šaltinis, kuris sukelia lokalią fibrozę.

\section{ASTMOS PATOGENEZE்}

Astma - tai lėtiné kvẻpavimo takų uždegimo liga, kuriai būdingas suaktyvèjusių eozinofilų, putliụjų ląstelių, Th2 CD4+ limfocitų, kartais ir neutrofilų (dažniau paūmèjimų metu) kaupimasis alveolių kapiliaruose, intersticiniame audinyje, alveolèse. Ja sergant vyrauja citokinai IL-4, IL-5, IL-13 (3 pav.). Dèl uždegimo padidèja bronchų reaktyvumas ịvairiems dirgikliams, ryškejja išplitusi, ịvairaus laipsnio, dažniausiai grịžtamoji (epizodinė) kvėpavimo takų obstrukcija, kliniškai pasireiškianti dusulio ar kosulio priepuoliais, praeinanti savaime arba gydant.

Tiriant astmos ligonių plaučių audinio biopsinę medžiagą, nustatomas padidèjęs kiekis ịvairių mediatorių:

- Th 2 ląstelių išskiriamų citokinų: IL-4, 5, 9 ir 13;

- prouždegimo citokinų: TNF- $\alpha$ ir IL-1ß;
- chemokinų: RANTES (angl. regulated on activation normal T-cell expressed and secreted), eotaksinuc ir monocitu chemotaksio baltymų (MCP)-1;

- augimo faktoriaus (TGF- $\alpha$, epidermio augimo faktoriaus) (1 lentelè).

Paūmejjimo metu eozinofiluc ir neutrofilu padaugèja kvėpavimo takų gleivinëje. Eozinofilai ir makrofagai išskiria mediatorius - histaminą ir cisteinilo leukotrieną (cys-LTs), kurie sukelia bronchospazmą, kvejpavimo takų edemą bei gleivių hipersekreciją. Sunkios astmos atvejais imunohistocheminiais plaučių audinio tyrimais nustatomas didelis kiekis eozinofilų ir netgi dar didesnis - neutrofilų bei jų išskiriamų mediatorių (Qiu Y. ir kt.; 2007) (4 pav.).

\section{IMMUNOHISTOCHEMICAL CHANGES IN COPD AND ASTHMA}

\section{ASTA JANUŠKEVIČIŪTE \\ DEPARTMENT OF PULMONOLOGY AND IMMUNOLOGY KAUNAS UNIVERSITY OF MEDICINE}

Key words: chronic obstructive pulmonary disease, asthma, immunohistochemistry, pathogenesis.

Summary. Asthma and COPD (chronic obstructive pulmonary disease) are two different inflammatory disorders of the lungs. Many cells are involved in the inflammatory response in asthma and, among these, CD4+ lymphocytes, mast cells and eosinophils are thought to play a crucial role. In COPD, the poorly reversible airflow limitation is associated with an abnormal inflammatory response of the lungs to noxious particles or gases [2]. This chronic inflammation is characterized by an increased number of CD8+ T-lymphocytes and macrophages in the lung tissue and neutrophils in the airway lumen. 